\title{
A kerti kakukkfü (Thymus vulgaris L.) fajták illóolaj-jellemzőit befolyásoló tényezők értékelése
}

Pluhár Zsuzsanna ${ }^{1, *}$ Szabó Dóra ${ }^{1}$, Katarzyna Seidler-Lozykowska², Tavaszi-Sárosi Szilvia ${ }^{1}$ Détár Enikö ${ }^{1}$, Zámboriné Németh Éva ${ }^{1}$

${ }^{1}$ Szent István Egyetem, Kertészettudományi kar, Gyógy-és Aromanövények Tanszék, Budapest

${ }^{2}$ Institute of Natural Fibres and Medicinal Plants, Poznan, Lengyelország

*e-mail: pluhar.zsuzsanna@kertk.szie.hu

A Thymus vulgaris illóolajának variabilitása jól ismert, melyet széleskörű kutatások eredményei támasztanak alá. Az egyes fajták produktivitása a különböző termesztő körzetekben azonban kevéssé feltárt. Ezirányú kísérleteink keretében párhuzamos szabadföldi kísérletek beállítására került sor 2014-2016 között Budapesten és a lengyelországi Poznanban, négy timol kemotípusba tartozó kerti kakukkfü fajta bevonásával: 'Varico 3' (V3), 'Sloneczko' (SL), 'Standard Winter' (SW) és 'French Summer' (FS). A három éven keresztül folyó vizsgálatok során értékeltük a termőhelyek (Budapest, Poznan), az évjáratok (2014, 2015, 2016), a növények fejlődési fázisainak (vegetatív, bimbós, virágzó, elvirágzott) és az állományok életkorának (1,2,3 éves) hatását az egyes fajták illóolaj-termelő képességére, valamint illóolajuk minőségére vonatkozóan.

Megállapítottuk, hogy jelentős különbségek mutathatók ki a fajták illóolajtermelő képessége és az illóolaj minősége tekintetében, melyet a termőhely, a növények életkora és az ontogenetikai fázisok egyaránt befolyásolnak. A fajták közül a 'Varico 3' kiemelkedő illóolaj-termelő képességgel rendelkezett, különösen az első évben (Poznan: 5,78 ml/100 g; Budapest: 3,97 ml/100 g). Az életkor előrehaladtával szignifikáns csökkenés következett be minden fajta illóolaj-tartalmában, mindkét termőhelyen (pl. Budapesten: 2014 (1. év): 2,78 ml/100 g; 2015 (2. év): 1,59 ml/100 g; 2016 (3. év): 1,09 ml/100 g). A termőhelyek közül Budapest összességében előnyösebbnek bizonyult minden fajta számára, ha a teljes életciklust vizsgáljuk, de az egyes évek és a fajták átlagát tekintve is (pl. 2016-ban: Poznan: 0,846 ml/100 g; Budapest 1,099 ml/100 g). A timol komponens illóolajban kimutatható aránya minden esetben a gyógyszerkönyvi előírásoknak $(40 \%<)$ megfelelő volt, de legmagasabb értékei a teljes virágzásban voltak mérhetők $(71,09 \%)$, melyet a vegetatív fázis követett (67,09\%), két év $(2015,2016)$ és a fajták átlagában. A fajták között azonban jelentősebb eltérések voltak kimutathatók a timol \%-os alakulásában (V3: 75,44\% $\rightarrow$ FS: $67,08 \%)$ és annak tendenciáiban egy (V3, SW) vagy két (FS, SL) maximum értékkel az 
adott tenyészidőszakon belül. E fajtatulajdonságok mérlegelendők a termesztés során, az állományok korának előrehaladtával, különösen a harmadik évtől.

\section{Köszönetnyilvánítás:}

Köszönjük az NKFIH-OTKA támogatását a nemzetközi együttmúködésben, NN108633 sz. alatt végzett kutató munkánkhoz. 